di- $n$-propyl and di-n-butyl compounds are all highly active, the propyl derivative showing the maximum activity. The compounds mentioned above are the most active of those so far investigated; then follow in order of activity neoergosterol, 5 : 6-cyclopenteno-1 : 2-benzanthracene, 1 : 2-benzpyrene, calciferol and ergosterol. That behaviour characteristic of a specific hormone should be shared by other compounds of related structure, some possessed of physiological activities of their own, provides a remarkable extension of our conceptions of biological specificity. It suggests future developments of great interest in the chemistry and biology of the sterols and the polycyclic hydrocarbons.

$1 \mathrm{~J}$. Soc. Chem. Ind., 51, 464, 954; 1932

2 Diels and Gadke, Ber., 60, (B), $140 ; 1927$

${ }^{3}$ Annalen, 459, 1, 1927; 478, $129 ; 1930$.

4 J. Soc. Chem. Ind., 52, 299; 1933.

5 ibid., 950.

${ }^{6}$ Nature, 132, 205, Ang. 5, 1933.

7 Rutenandt, J. Soc. Chem. Ind., 52, 268, 287 ; 1933.

${ }^{8}$ Cook, Hewett and Hieger, J. Chem. Soc., 395; 1933.

Proc. Roy. Soc., B, 111, 455, 485 ; 1932.

10 Jacobs and Fleck, J. Biol. Chem., 87, 57 ; 1932

11 NATURF, 132, 1933.

12 Discussed at a meeting of the Royal Society on Nov, 16, 1933.

\title{
Obituary
}

\section{Prof. Erwin Baur}

$\mathrm{B}^{\mathrm{Y}}$ $Y$ the sudden death of Prof. Erwin Baur at the early age of fifty-eight years the science of genetics, and particularly plant breeding, has lost one of its foremost exponents. Having gone to Berlin to give an address at Harnack House on December 2 in commemoration of Correns, whose death was recorded only a year ago, he was suddenly struck down with angina pectoris and died within a few hours.

Baur was born in 1875 at Ichenheim in Baden, the son of an apothecary. He studied medicine in several German universities and was for one year assistant in the Botanical Institute at Kiel, receiving the degree of doctor of medicine in 1900 . He served as ship's doctor on a voyage to Brazil, followed by a year of service in the navy. He was afterwards assistant physician in the psychiatric clinic of the University of Keil and physician to an institute in Baden for the insane. In 1903 he returned to botany and received the $\mathrm{Ph} . \mathrm{D}$. at Freiburg under Oltmanns, his thesis being on the development. of the apothecia in lichens. Apparently his first botanical paper was on the sex organs of the lichen Collema (Ber. deut. bot. Gesells., $16,1899)$, the figures from which have frequently been reproduced in textbooks. Baur now migrated to Berlin as assistant in botany, where he became full professor and director of the Botanical Institute of the Königliche Landwirtschaftliche Hochschule in 1911.

The rest of Baur's life was not only actively devoted to research in plant genetics and its applications (except for the last two years of the War, when he was transferred to Potsdam with his staff), but also in this period he founded and directed successively a new Institut für Vererbungslehre in Berlin-Dahlem in 1922 and a still larger Kaiser Wilhelm Institut für Züchtungsforschung at Müncheberg, some distance from Berlin, in 1929 .

Erwin Baur was a man of tremendous energy and vigour, but overwork brought his life to an all too early end. His well-known genetical investigations of Antirrhinum were begun about 1904, and already in 1910 he was growing some 30,000 antirrhinums a year. $\mathrm{He}$ also made the early studies of infectious chlorosis in Malvaceæ,
Ligustrum, Fraxinus and other plants, and his investigations of graft hybrids and chimæras in Pelargonium and other plants were notable. His "Einführung in die experimentelle Vererbungslehre", first published in 1911, has passed through eleven editions, and fulfilled somewhat the same functions in Germany that Bateson's well-known "Mendel's Principles of Heredity" did in England.

In a series of classical researches, Baur first investigated the large number of colour factors and other mutational differences in the garden snapdragons. Later his interest in the evolutionary aspects of the genus developed. $\mathrm{He}$ collected and studied the wild species of Antirrhin$u m$ from Spain and other Mediterranean countries, finding throughout the genus that the specific differences behaved as Mendelian characters in crosses. At the Müncheberg Laboratory the same genus was extensively used by Baur, Stubbe and other colleagues in the production of an extraordinary series of mutations in flower and leaf form by the use of X-rays, ultra-violet light, temperature shocks and a wide range of chemical substances. These substances were forced into the leaves through the stomata by centrifuging seedlings which were inverted in tubes containing the solutions. The plants were then set out and allowed to flower. Baur's great knowledge of the wild forms of Antirrhinum, their distribution and genetics, will unfortunately be lost, as it had not been put in a form for publication.

Baur's interests lay not only in the wider aspects of genetics but also in their application. This was exemplified in the Masters Lectures of the Royal Horticultural Society, which he gave in 1931. His general evolutionary outlook was that of Darwinian natural selection based on mutational variations, but the aims of the Müncheberg Institution were immediately economic. Baur set about to produce a wheat suitable for light soils in Germany in place of rye, by crossing and selection on a huge scale. By the testing of one and a half million lupins, plants were found in both the yellow and the blue species which were devoid of alkaloid and could be propagated as a forage field-crop. By similar large-scale selection a variety of Melilotus alba was obtained free from cumarin, and a tobacco 
free from nicotin Efforts were being made to produce a grape whioh was resistant to Phylloxera and Peromospora, by extensive crossing with North American varieties and subsequent selection. Baur visited Peru and Bolivia, bringing back many native varieties of potato for use in plant breeding. Other large-scale crosses were made for the improvement of gooseberries, raspberries, blackberries and tomatoes.

In 1908, Baur founded and edited the Zeitschrift fuir induktive Abstammungs- und Vererbungslehre, which has remained one of the standard journals for genetical researches and publishes a comprehensive classified bibliography of the world literature. $\mathrm{He}$ also founded the Bibliotheca Genetica, Der Züchter, and was joint editor of the Zeitschrift für Pflanzenzüchtung Gartenbauwissenschaft and Berichte über die gesamte wissenschaftiche Biologie. With Dr. M. Hartmann he had produced since 1928 the "Handbuch für Vererbungswissenschaft". He was thus instrumental in giving publication to a very large amount of important genetical work. Baur, with Fischer and Lenz, wrote the well-known "Menschliche Erblichkeitslehre und Rassenhygiene", which has seen several editions. At the fifth International Congress of Genetics, held at Berlin in 1927, he was a leading spirit and gave the opening address as president of the local committee.

Prof. Baur was an honorary member of many scientific societies and was elected a foreign member of the Linnean Society of London in 1933. An indefatigable worker, his results have been among the most fruitful in modern plant genetics.

R. Ruggles Gates.

\section{Prof. W. E. GibBs}

IT is with great regret that we record the death on January 18 of Prof. William Edward Gibbs, at the early age of forty-four years. Prof. Gibbs was the Ramsay professor of chemical engineering at University College, London, having been appointed to that post on the resignation in 1928 of Prof. E. C. Williams. At the time of his appointment a large extension of the Department of Chemical Engineering had been planned, as the result of generous donations from various important British chemical firms, obtained through the energetic propaganda of his predecessor. The extension was designed and carried out by Prof. Gibbs with conspicuous ability and success, and within a few years his genial personality, combined with his deep interest in research, his organising power and his practical knowledge of industrial methods and processes, had filled the much enlarged laboratory with a band of enthusiastic students drawn from many sources-young British university graduates, experienced men from various industries, and foreign students.

Prof. Gibbs was a graduate of the University of Liverpool, and obtained his first post as assistant chemist to the Straits Trading Company at
Singapore. Having held this post for a few years he returned to the University of Liverpool, and the present writer recollects the enthusiasm with which he attacked the problem of the electrochemical recovery of metallic tin from the waste smelter material which he had brought home with him. At Liverpool he was soon appointed lecturer in metallurgy, and he was also made investigator to the Corrosion Committee of the Institute of Metals.

During the War, Prof. Gibbs rendered valuable service to the country, holding successively the posts of chief examiner of the Aeronautical Inspection Department, and chief chemist to the Government Rolling Mills at Southampton. At the conclusion of the War he was appointed chief chemist to the Salt Union, a post which he held until appointed professor at University College. During this period he acquired an extensive practical acquaintance with the technical methods and problems relating to evaporation and crystal. lisation.

Prof. Gibbs was deeply interested in the properties and treatment of aerosols and aerogels, that is, disperse systems in gases, and wrote two excellent books, "Clouds and Smokes", and "The Dust Hazard in Industry", which are, so far as the present writer is aware, the first scientific expositions of these important subjects in book form in the English language. He was also very much interested in problems relating to heat exchange, the flow of liquids and gases, the fractional distillation of liquid mixtures and the design of gas-scrubbers and rectifying columns. In these and other fields of chemical engineering he understood well how to combine the theoretical basis of design with the practical aspects of construction and operation, and he possessed the supreme gift of awakening and sustaining the intelligent interest of his students and securing their loyal and indeed affectionate co-operation.

Prof. Gibbs was a man of high, unselfish and sterling character, combined with an endearing charm and simplicity of personality not often encountered in this world. His untimely death is a severe loss, not only to his colleagues and students at University College, but also to the Institution of Chemical Engineers and the science and practice of chemical engineering throughout the world.

F. G. D.

\section{Dr. Hermann Christ-Socin}

BARELY three weeks before his hundredth birthday, and still fully in possession of his physical and mental faculties, Dr. Hermann Christ, the Nestor of European botanists, had the misfortune to slip on the polished floor of his stady and to fracture his leg. Unfortunately, too, complications set in and he died on November 24 at his home in Riehen near Basle.

Though known throughout the world as a botanist, Dr. Christ was by profession a lawyer, for which career he prepared himself by studies in the Universities of Basle and Berlin. But, interested 